\title{
Information management as a determinant of success in knowledge management systems
}

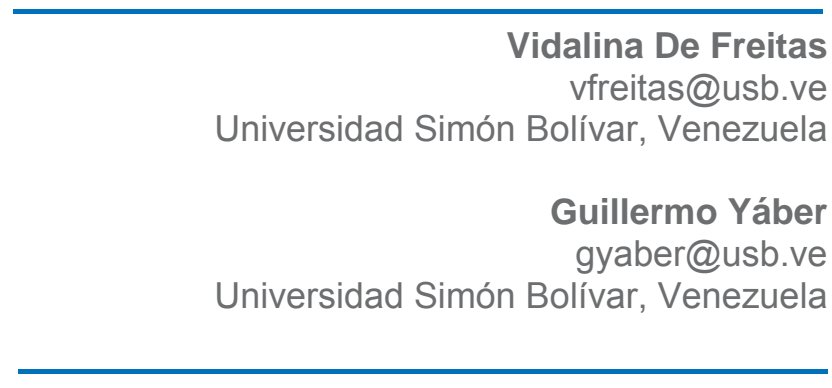

\begin{abstract}
Universities, to achieve success and stay competitive, must refine their processes by way of new methods and technologies to enable development and transfer the knowledge they create, utilizing valuable knowledge more productively in academic and learning services; in the management of research projects, community activities, and the student life cycle; and in institutional development, support and administration. An efficient knowledge management system (KMS) is an important strategy for helping universities to achieve sustainable competitive advantages. However, many have embarked upon the KM process without knowing what factors are required for successful KMS implementation. The aim of this article is to explore the influence of information management (IM) as one of the determinants of success in KMS implementation, particularly at the Universidad Simón Bolívar, a public institution located in Caracas, Venezuela. The design we employ is exploratory rather than experimental. We take a deductive approach, based on a quantitative method, and employ a questionnaire for data collection. Our sample is made up of 96 participants (academic and support staff). We concludes by acknowledging the importance of IM as a success factor for effective $\mathrm{KM}$, with the participation of different actors in the decision-making process.
\end{abstract}

Keywords: Information, knowledge, management, universities. 
De Freitas, V. \& Yáber, G. (2018). Information management as a determinant of success in knowledge management systems. Journal of Business, Universidad del Pacífico (Lima, Peru) Vol.10 (2): 88-108

\section{Introduction}

Competitive advantage is a key factor for an organization to advance in the era of globalization, information societies (IS) and knowledge societies (KS). And this competitive advantage is driven by the knowledge economy.

UNESCO (2005: 17) distinguishes between an IS and a KS, understanding the former in terms of technological progress and the latter of deeper social, ethical, and political dimensions; moreover, whereas the former provides tools for the accumulation of information, the latter utilizes these tools in reasoning processes.

According to De Freitas (2017), unlike the traditional economy, founded on tangible goods or property, the new, knowledge economy is based on intangible goods where knowledge is the predominant factor of production.

For UNESCO (2005), in the social change that is leading to knowledge societies, knowledge emerges as a strategic resource necessary for sustainable development.

Bradley (1997) proposes that knowledge has become a major exponent of wealth generation and competitive advantage for organizations. As such, as Barney (1991); Grant (1991); Hall (1992); and Barney, Wright and Ketchen (2001) point out, the importance of intangible resources, which determine strategic positions of organizational growth, has become evident.

Today, in the words of Escobar, Velandia \& Navarro (2018: 91), "organizations present themselves as agents integrated by resources and capacities, whose end is established in the satisfaction of the needs expressed by stakeholders, based on the generation of benefits that go beyond the financial sphere, tending toward the sustainable development of society through the implementation of administrative strategies that seek to respond to the basic questions of the economy, with a high degree of responsibility".

Given that knowledge has become the most important factor of production, organizations must center on its production, acquisition, distribution, retention, and application (Shaikh, 2004).

It is important to manage this resource, since $\mathrm{KM}$ adds value to organizations in terms of competitive advantage (Hall, 2006); improved financial performance (Teece, 2005); innovation (Nonaka \& Takeuchi, 1995; Carneiro, 2000); anticipation of problems (Carneiro, 2000); productivity (Kane, 2010); strategic positions of organizational growth (Barney, 1991; Barney, et al. 2001; Grant, 1991; Hall, 1992; Kane, 2010); maximization of organizations' learning achievements (Almuiñas, Passailaigue \& Galarza; 2015); and superior use of information (Carneiro, 2000).

Universities, as higher education institutions (HEls), are organizations; as such, they must also preserve their knowledge and provide continuity to critical processes by profiling knowledge as a strategic aspect, placing importance on supporting the organization's functions; satisfying stakeholders' needs; pursuing better financial performance, productivity, and teaching quality; and promoting innovation and competitive advantage, among others. But it is critical that HEl administration establish "management mechanisms that promote the generation of competitive advantages, based on the assertion of all knowledge in its tacit dimension, if they want to be sustainable on a stage that requires a high degree of social responsibility and specialization in the products and services offered to society" (Seguí, 2007; Flores \& Ramírez, 2011)" (Escobar et al., 2018). Thus, strategic management systems must 
generate useful and relevant information for the development of competitive strategies (Otálora \& Vásquez, 2016).

It is therefore necessary to speak of information insofar as there would be no organization without it, since economic development is considered to depend increasingly on information and knowledge (Almuiñas et al., 2015). Indeed, information and knowledge are recognized for their leading role as new economic resources and factors in what has been called the information and knowledge era.

HEls generate knowledge in the execution of their daily activities (academic and administrative processes): explicit knowledge, in the form of documents, procedures, and results; and tacit knowledge, in the form of the experiences, opinions, perceptions and points of view residing within people.

As far as $\mathrm{KM}$ is concerned, there are two perspectives. On the one hand, the perspective centered on coding knowledge, referred to in one way or another as IM, seeks to manage explicit knowledge; and on the other, the person-centered perspective stresses the importance of tacit knowledge and the social infrastructure for sharing it (for example, communities of practice). It should be noted that information becomes knowledge when a person has contextualized it, such that the process improves their capacity to act intelligently.

However, many HEls have started the KM process without fully recognizing that IM is a prerequisite for its success (Bustelo \& Amarilla, 2001; Orozco, 2004; Ponjuán, 2005; Sánchez \& Vega, 2006; Makori, 2009; López, 2011); others believe that initiating KM requires the disappearance of all the potential stored in IM through information systems developed over the years, with the loss of important information; while others still are of the opinion that IM occurs in parallel with $\mathrm{KM}$, without understanding that the integration of both enhances the benefits that can be obtained from the organization's current resources, favoring collective learning and teaching quality. IM is important because it manages explicit knowledge.

The aim of this study is to explore the importance of IM as one of the determinants of success in KMSs. It draws on the holistic model of KMSs proposed by De Freitas and Yáber (2014), utilizing information collected from two Venezuelan universities that have started the KM process, Universidad Central de Venezuela (UCV) and Universidad Simón Bolívar (USB), where IM is regarded as a key element to be taken into account during this process.

The study is structured as follows: first, we conduct a review of the literature, focusing on the distinction between data, information, and knowledge and between IM and KM, as well as on IM as a factor determining the success of KM. We then describe our methodology, analyze the data yielded through the quantitative method, and present the conclusions.

\section{Theoretical Framework}

In this age of information and knowledge societies, HEls, particularly universities, play an increasingly important role in training individuals who have the critical skills and thought structures to transform information into knowledge, assuring the effective practice of their professions and leadership in both the public and private sectors.

Information and knowledge underlie all processes and, in some more than others, communication is the means of exchange par excellence. Since information and 
knowledge are key elements in the functioning of organizations, particularly universities, any thought or action related to them in terms of content, quantity, quality, timeliness, pertinence, and forms of management, transmission and acquisition, and so on, will be vital for improving the quality of higher education (Almuiñas et al., 2015, p. 7) and its management.

Thus, the process used by the agents with administrative responsibilities at universities must be efficient and oriented toward competitiveness and the creation of value for stakeholders (Guzmán, Santos \& Barroso, 2015; Peraza, Gómez \& Aleixandre, 2016).

Improvements in educational quality are the sum of efforts to achieve the objectives and strategies set at each institution. IM and KM are two of the main tools that have emerged to this end, facilitating proper, timely collection of information pertaining to the corresponding individuals and making it available to all who are active at HEls, in order to aid and improve decision-making as well as their products and services. Through access to adequate and timely information, staff can apply it at the right time and thus turn it into knowledge.

To distinguish between IM and $\mathrm{KM}$, it is important to review the concepts around both information and knowledge.

\section{Differentiating between information and knowledge}

Data in itself do not assist with HEI management, but transformed into information, they become a tool for managing these institutions (Garita, 2015, p. 26).

Information is made up of a set of structured and/or processed data, of relevance and use to those who receive it. Information must be classified to be considered important (Garita, 2015). And information, to become knowledge, must be relevant, accurate, complete, appropriate at the moment of submission, timely, and understandable to the recipient (Garita, 2015, p. 27). In these terms, a synonym of information is explicit knowledge.

Knowledge, for its part, is authenticated information. Knowledge is produced when an individual makes use of what they know and the information available to solve a problem or develop a project (Bustello \& Amarilla, 2001). Knowledge "results from the Integration of information into a context of experience and existing knowledge" (Pircher \& Pausits; 2011, p. 9). In this context, information is the basis of knowledge (Almuiñas et al., 2015). Knowledge is found in the human mind, the result of each individual's experience and thoughts based on a set of beliefs. Knowledge is more complex than information, and the difference lies in the role played by the human being; in the case of knowledge, individuals take the lead as creators, broadcasters, and users (Fotache, 2013). However, in the case of information, these functions can be performed "beyond" persons, without their direct influence (Fotache, 2013).

For Ponjuán (1998) "information is a vital resource for the development of an organization, and knowledge is a process that leads to analysis, reasoning and intelligence" (p. 135). 
As noted earlier, knowledge can be either tacit or explicit. Tacit knowledge is that which resides within individuals. It is either not transferable at all, or only partially transferable to a very minimal degree, even if it is in written or verbal form (Polanyi, 1998). In turn, explicit knowledge is that which can be transferred to a greater or lesser extent from one person to another (Polanyi, 1998), and may be contained in statistical or coded sources.

\section{Information management}

IM is defined as the process of locating adequate information, in the suitable form, for the appropriate person, at the relevant cost, at the right time, in the required place, to take the necessary action (Woodman, 1985).

Rodríguez and González (2013), note that IM "is based on achieving connectivity in information processes; by creating interfaces, databases and information transfer, through the internet, guaranteeing permanent updates" (p. 98).

According to Almuiñas et al., (2015), insofar as "the organizational structure facilitates synchronization between person and information, a far greater environment of understanding will be created within the organization; this is one of the essential objectives of $\mathrm{KM}$, and so the necessary conditions for carrying it out are conditioned by: the quality of the human factor and the capacity to manage information" (p. 19). Thus, $\mathrm{KM}$ must ensure that high-quality information exists, considering that information is only useful if it is turned into one of the most valuable assets: knowledge (Garita, 2015).

Only when information is timely, accurate, and relevant is knowledge possible; and its real value can only be attained through the use of knowledge and competencies (Pircher \& Pausits, 2011).

$\mathrm{KM}$ represents the process through which an organization collects, compiles, organizes, stores, controls, and disseminates information, making sure that its value is fully identified and exploited (luga \& Kifor, 2014, p. 32); it is the key to sustaining the creation and application of knowledge in organizations. Given that explicit knowledge is understood as information, it can be said that IM only manages part of knowledge. IM manages explicit knowledge, manifested as procedures, rules, documents, articles, and books, among others. In turn, the other form of knowledge, difficult to collect and transfer, pertains not to IM but to KM. Considering that KM is supported by the pillars of IM, it must be practiced with quality and the proper infrastructure, with technology backing tacit information.

Thus, to guarantee efficiency in $\mathrm{KM}$, and as proposed by the Centro Interuniversitario de Desarrollo (1997, p. 191), it is necessary to take two aspects into account: the systemic approach to understanding HEls as an integrated system within a specific culture; and the role that information plays as a means of increasing learning capacity at educational institutions, where systemic thought refers to the dynamic interactions of each of the elements that make up a system.

In this regard, KMSs must pursue distributed and integrated processing systems that allow for a comprehensive approach, with the aim of achieving linkage, interconnectivity and interdependence in their processes, while ensuring they are oriented toward users

- that is, by providing them with the information they require for their jobs. These 
systems must integrate all modules and/or subsystems that support the activities related to academics, students, researchers, support units, extension, student and social wellbeing, library services, foundations, technology parks, and so on. In sum, an information system must address all processes that add value to the institution's objectives.

Based on IM, KM is focused on the set of processes that enable the use of knowledge as a key factor in adding and creating value.

\section{Knowledge management}

As Kazemi and Allahyari (2010) observe, there is no single, agreed definition of KM, and on many occasions it is confused with IM (Milam, 2005).

For St Clair (2001), the perception or definition of KM depends on the person doing the theorizing and their specialization, reflecting their origins as well as their ideological, philosophical, and pragmatic position (Rueda, 2014, p. 53).

Almuiñas et al., (2015), define KM as "the set of activities carried out in order to utilize, share, and develop the knowledge of an organization and the individuals who work there, leading them toward better attainment of their stated aims and targets" (p. 20). This takes into account aspects of management such as process planning, organization, execution, and control in order to achieve certain objectives; collecting and/or receiving information from within and without; its recognition organization, storage, analysis, and assessment; and the sending of an external response so as to achieve a satisfactory outcome.

KM represents a methodological approach to increasing a firm's capacity while improving decision-making and the strategy formulation process (Ooi, 2009). Thus, KM forms part of the strategy that helps organizations to address competition, globalization, the economy, and rapid technological change through the creation of effective knowledge, allowing them to increase their intellectual capacities and achieve competitive advantages (Kotecki, 2011).

In turn, Almuiñas et al. (2015: 21), note that for organizational learning to occur, there needs to be "adequate use of staff members' skills; the creation of a working environment that encourages individuals to learn more and more; the creation of spaces favorable to sharing and distributing information among all members of the organization so that they can use it and convert it into individual knowledge and, subsequently, into organizational knowledge; as well as development of institutional capacities for facing increasingly complex problems". This constitutes a continual process of creating values and intangibles.

For Pircher and Pausits (2011), a basic KM model is composed principally of two different subsystems: the social subsystem, comprised of human beings, and the documentary subsystem. The human beings in the social subsystem possess knowledge that forms the basis of actions, which generate experience that, in turn, trigger learning processes, giving rise to new knowledge. But these actions can also lead to documentation, or the second subsystem, which represents another way in which humans develop knowledge.

In this regard, these are two strategies aimed at managing knowledge transfer: the strategy focused on tacit knowledge (personalization), and that aimed at explicit knowledge (coding). The personalization strategy is centered on human beings, 
emphasizes interpersonal interactions through face-to-face contact, may or may not be supported by information and communication technology (ICT), and promotes the acquisition and exchange of knowledge. Meanwhile, the coding strategy seeks to use documents to capture the knowledge residing in persons. In this case, HEls must know, in advance, what type of strategy they want to develop. And if they pursue both, they advantages could be greater.

Indeed, both IM and KM share a single purpose: for organizations to achieve their aims in order to be competitive.

\section{Knowledge management at higher education institutions}

The emergence of the knowledge economy has brought about a change in the meaning and value of knowledge for society (Núñez \& Rodríguez, 2014), in which competitive advantage lies in the capacity to acquire, transmit, and apply knowledge in a continual cycle that encompasses the capabilities of individuals, organizations, and society, and which generates social, economic, and financial benefits (Sáiz et al., 2013).

As explained by Escobar et al., (2018), the resources and capabilities theory of Penrose (1959) and Barney (1991) center the dialogue on analyzing Porter's (1991) causes of competitive performance from the perspective of internal factors, whereby knowledge, as an intangible resource, constitutes an asset that can guide an organization to a competitive market position.

Since knowledge is a resource in itself, appropriate KM will enable the maximization of all benefits that can be extracted from it, as KM "has an important role in providing a systematic structure to support the conversion of resources into capacities in a systematic way" (Cruz, 2012, p. 368).

Thus, HEls, just like any other organizations, are immersed in the knowledge economy, where they compete based not on what they have but on what they know. In a globalized world underpinned by knowledge, HEls must face the challenge of being sustainable, efficient, and attaining appropriate quality levels in education, research, extension, and management.

As such, HEls are compelled to be flexible to adapt to changes, develop technology intangibles to foster information, and modernize academic processes, resulting in curricular and management structures that allow results to be shared and made compatible (Varela-Candamio \& García-Álvarez, 2012).

In this sense, HEls must strengthen their capacities to create intangibles by facilitating the education process. These institutions must promote better performance and quality levels, adapt their processes to changes, and strengthen strategic advantages that by taking advantage of intrinsic resources and capacities, which are largely intangible (Morales, Medina \& Álvarez, 2003). HEls are framed by the triple helix theory (Luengo \& Obeso, 2013), which involves developing the capabilities of these institutions to connect with the productive and public sectors; thus, they must assume a role as creators, innovators, and transmitters of knowledge, technology, and innovation in order to act as engines of socioeconomic development (Núñez \& Rodríguez, 2014, p. 151). As a result, 
there is a need for new, intangibles-based models of interaction within universities (Rodríguez-Ponce et al., 2013).

For Naranjo, González \& Rodríguez (2016), universities, as HEls, "are knowledge organizations, given that this is the main value in their training, research, and extension activities" (p. 161); this represents the paradigm of displacing the historical capital-labor model with one of information and knowledge. KM theory in HEls has three areas of reflection: identification of research priorities; study of intellectual capital and intangibles; and projection of institutions in their environment to promote the social appropriation of knowledge.

Al-Hayaly \& Alnajjar (2016, p. 75) argue that KM at universities promotes increased innovation and output by the teaching faculty; enhances each institution's capability for effective economic development through a fruitful economic role in serving stakeholders and developing human capital and infrastructure for appropriate use of technology; and aids university performance and links it directly with society based on knowledge of market needs, establishing pertinent curricula and effective teaching methods for the service of society.

In sum, HEls, to be competitive, must be able to manage their resources and capacities with a view to promoting collective learning and improving the quality of the academic processes in which they operate.

\section{Knowledge management systems}

Ruzic-Dimitrijevic (2014) defines KMSs as the collection of three subsystems: people interactions; technology acting, or incorporating; and organizational structures.

For Noordin, Othman \& Zakaria (2013), the key factors to be taken into account for successful KMS adoption and implementation are: efforts/strategies (infrastructure, training, resources for generating knowledge, motivation, among others); limitations of current KMS (insufficient functionalities, lack of information and knowledge stored in the repository, among others); and inhibitors in terms of infrastructure and an attitude of resignation.

\section{Information management as a determinant of success in knowledge management}

Gates (1999) points out that KM "starts with business objectives and processes and a recognition of the need to share information. Knowledge management is nothing more than managing information flow, getting the right information to the people who need it so that they can act on it quickly" (p.238).

For Makori (2009, p. 85), KM is a prerequisite of KM, and forms part of it.

According to Bustelo and Amarilla (2001), KM is impossible without adequate IM and document management (DM).

Sánchez and Vega (2006) propose that "the implementation of a KM model must be founded on an effective IM system, as a fundamental pillar for knowledge management is access, availability, and sharing of information" (p. 40). This is validated by Pubillones (2004), who finds that a key ingredient of $\mathrm{KM}$ is proper IM, since knowledge is 
De Freitas, V. \& Yáber, G. (2018). Information management as a determinant of success in knowledge management systems. Journal of Business, Universidad del Pacífico (Lima, Peru) Vol.10 (2): 88-108

constructed from the information received, stored, and transmitted through messages with informational content.

Orozco (2004), for his part, notes that the main IM principles (identification of information needs; acquisition of information sources; organization and storage; development of products and services; distribution and use) are also the basis of knowledge creation in organizations, and are therefore fundamental for the initial stage of KM.

$\mathrm{KM}$ is partly based on IM, as documents are an explicit crystallization of knowledge and are stored in the form of documents or knowledge units (López, 2011).

For Blanchard (2000), the concept of KM entails the strategic development of the following areas: DM, IM, resource organization and management, and innovation and change management.

$\mathrm{KM}$ has been said to rest on four pillars: individuals, processes, content, and information technology, each of which encompasses aspects that can influence the effectiveness of KM practices in organizations (Gómez-Vargas \& García, 2015).

In turn, López (2011) proposes that KM is comprised of the fundamental pillars of information, the environment, and individuals, along with ICT, which greatly facilitates the process. Indeed, human interaction, learning, and tacit knowledge, among other factors, are indispensable to achieving the maximum knowledge possible, always aided by ICT.

In this regard, Sánchez \& Vega (2006) stress that: "the information dimension will tend to grow in companies based on KM if adequate use is made of it; it is necessary to design a strategy that allows the development of an effective information management system" (p. 40), in recognition of IM's importance as a precursor to KM.

For adequate $\mathrm{KM}$, it is necessary to understand and exploit its tacit nature; create the settings and processes that allow for its exploitation; inventory the stock of knowledge (what is it that we know?); increase it while simultaneously acquiring new knowledge available for those who require it; and conserve, invigorate, and improve it, establishing its real contribution to the organization (Naranjo, 2011).

Moreover, linking KM with DM and IM systems ensures its effectiveness. This is because the synergy between these systems constitutes a condition and a requirement for adequate work with documents, information, and organizational knowledge (Ponjuán, 2005). In other words, the interrelation or common ground between DM, IM, and KM lies in the conversion of tacit into explicit knowledge (Ponjuán, 2005), as shown in Figure 1.

Both IM and KM depend on individuals, but they have very different aims. The purpose of IM is to provide information based on the collection of stored data. In turn, KM is focused on organizational outcomes. IM meets its objective when it guarantees data preservation and recovery. Successful KM occurs when knowledge exchange takes place between employees. As such, KM is more than IM; the former aims for knowledge to be acquired and learned based not just on experiences, but pre-established information. It is notable that when individuals produce/internalize information, they are carrying out a transformation; that is, the information becomes knowledge. 
De Freitas, V. \& Yáber, G. (2018). Information management as a determinant of success in knowledge management systems. Journal of Business, Universidad del Pacífico (Lima, Peru) Vol.10 (2): 88-108

Figure 1. Integration of document, information and knowledge management systems

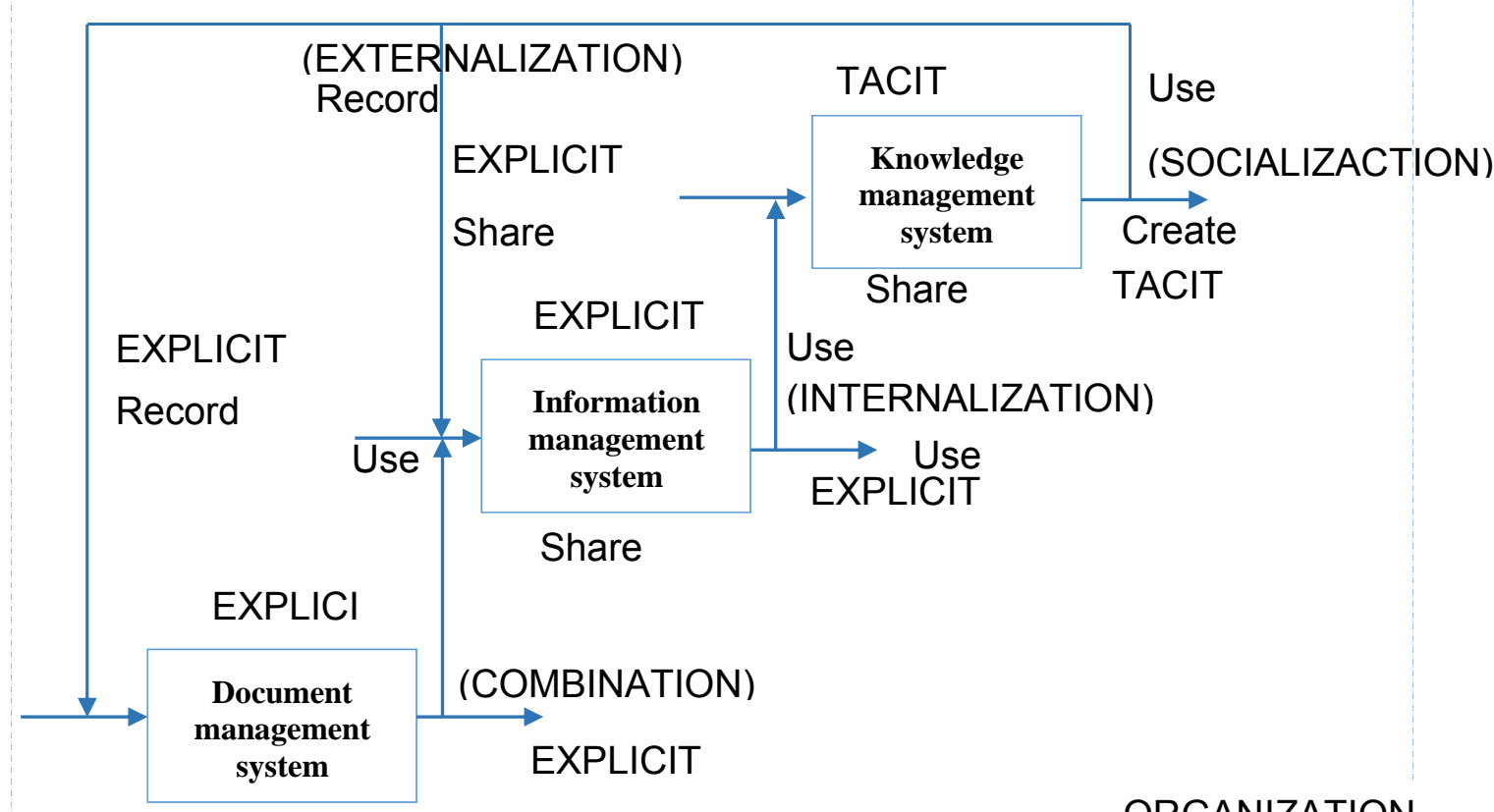

ORGANIZATION

Source: Ponjuán (2005)

On this point, there is evidence that IM is an essential pillar of KM (Bustelo \& Amarilla, 2001; Pubillones, 2004; Ponjuán, 2005; López, 2011; Naranjo, 2011; Almuiñas et al., 2015), alongside organizational culture, intensive use of ICT, and management of human resources.

In sum, $\mathrm{KM}$ is linked to different forms of management, such as $\mathrm{IM}$, technology management, and human resource management, among others. That is, KM cannot be implemented in isolation. This, and its use, depend on other forms of management (Sánchez \& Vega, 2006).

\section{Conceptual model}

Our conceptual model of the importance of IM as a determinant of success in KMS implementation (see Figure 2), is based on Stankosky (1999); Bustelo and Amarilla (2001); Suárez (2009); Cáceres (2011)M and De Freitas and Yáber (2014); while the measures of success in KMS implementation are based on DeLone and McLean (2003); Halawi, McCarthy and Aronson (2008); Nattapol, Peter and Laddawan (2010); Jennex and Olfman (2011); and Astuti and Suryadi (2015).

Figure 2 Information management as a determinant of success in KMS implementation

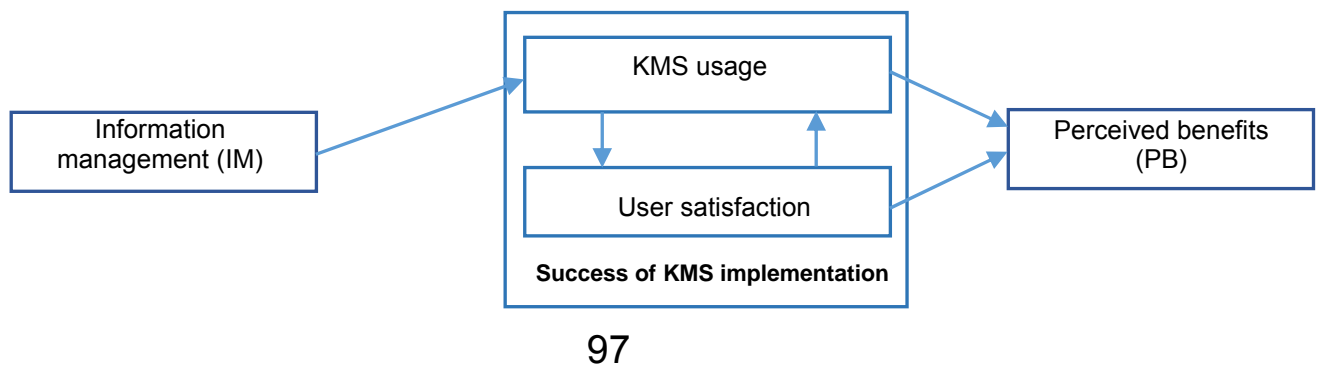


Information management

Earlier studies have found that important success factors in KMS implementation include strategies and policies aimed at adequate IM, including DM (both internal and external), through a comprehensive approach: a distributed and integrated processing system that enables process linkage, interconnectivity, and interdependence.

Hypothesis 1: There is a positive relationship between IM and KMS usage

\section{Success of KMS implementation}

KMS usage and user satisfaction are two measures of success in KMSs (Halawi et al., 2008; Nattapol et al., 2010; Jennex \& Olfman, 2011; Astuti \& Suryadi, 2015). The risk of failure in KMS implementation exists on two fronts: in the implementation process itself; and in the process of pursuing the system's objectives through its adoption and usage.

KMS usage

KMS usage is a construct that measures success in KMSs (DeLone \& McLean, 2003; Halawi et al,, 2008; Nattapol et al., 2010; Jennex \& Olfman, 2011; Astuti \& Suryadi, 2015), and is understood as the knowledge, attitude, and action of using an existing, operational system, for the purposes of decision-making, exchange, and recording and transferring knowledge (Maier, 2007).

Hypothesis 2: There is a positive relationship between KMS usage and user satisfaction.

\section{User satisfaction}

User satisfaction is a construct that measures KMS success (DeLone \& McLean, 2003; Halawi et al., 2008; Nattapol et al., 2010; Jennex \& Olfman, 2011; Astuti \& Suryadi, 2015) in terms of user satisfaction with KM. It is regarded as a good complimentary measure of KMS usage, as the desire to use a KMS depends on users' satisfaction with it (Jennex \& Olfman, 2011, p. 22). An increase in user satisfaction has a positive influence on KMS usage in terms of effectiveness (DeLone \& McLean, 2003), and further usage (Nattapol et al., 2010).

Hypothesis 3: There is a positive relationship between user satisfaction and KMS usage.

\section{Perceived benefits}

This metric assesses the benefits derived from using a KMS and being satisfied. It refers to processes that allow for the identification, distribution, and utilization of knowledge in daily decision-making processes (Jennex, 2017).

Hypothesis 4: There is a positive relationship between KMS usage and the perceived benefits

Hypothesis 5: There is a positive relationship between user satisfaction and the perceived benefits 
De Freitas, V. \& Yáber, G. (2018). Information management as a determinant of success in knowledge management systems. Journal of Business, Universidad del Pacífico (Lima, Peru) Vol.10 (2): 88-108

\section{Methodology}

In Venezuela, there are twenty (20) public universities (Universidad Central de Venezuela, 2013), of which two (2) as of 2013, had started the KM process. On this basis, De Freitas and Yáber (2014), propose a holistic KMS model for the HEI by way of a qualitative study, finding that IM is a key factor to be taken into account for KM.

The aim of this present study is to explore the influence of IM as one of the determinants of success in KMS implementation, drawing on the earlier model of De Freitas and Yáber.

To this end, we selected the Universidad Simón Bolívar (USB) given its size and organizational structure, which is perceived as the most accessible. The USB has implemented a KM information system (KMIS) known as Pyxis.

Our design was exploratory rather than experimental. We took a deductive approach, based on a quantitative method.

The population was made up of a total of 210 informants. We used a convenience sample, selecting individuals with positions (academic or administrative) at the university. Of the total population, we obtained 96 valid instruments $(45.23 \%)$.

Our instrument, a questionnaire, corresponds to Section 3 of the instrument applied to USB as part of Freitas and Yáber (2014), the aim of which was to obtain information on user perception about the use of the KMIS, critical success factors, and the level of maturity achieved by the university in these terms, among others, In particular, we sought to identify participants' perceptions on the importance of IM at that institution and its influence on the KMIS known as Pyxis. To this end, we used the Likert scale, from 1 to 5 , with possible answers ranging from "totally disagree" to "totally agree".

\section{Data analysis and results}

We performed the statistical analysis using the SPSS program, version 17.0.

First, we applied descriptive statistics to analyze the demographic data pertaining to those surveyed. Second, we assessed the instrument's reliability and validity. Third, we applied the correlation matrix and factor analysis approaches to examine the validity and reliability of the constructs. Finally, we tested the hypotheses by way of multiple linear regression analysis.

\section{Descriptive statistics on those surveyed}

-Gender

The group was made up of 49 (51.04\%) men and 47 (48.94\%) women.

-Staff category

Of the total sample, $63(65.6 \%)$ were academics, and $33(34.4 \%)$ were support staff.

-Education level

Of the support staff, who are not required to possess higher qualifications, $3.03 \%$ (1)

had a bachelor's degree; $45.5 \%$ (15) an undergraduate degree; $27.3 \%$ (9) had a

"specialist's" degree, a qualification under the Venezuelan system; $24.2 \%$ (8) had a

master's degree. As to the teaching staff, $6.3 \%$ (4) had an undergraduate degree; $1.5 \%$

(1) had a specialist's degree; $41.3 \%$ (26) a master's degree; and 50.8\% (32) a doctoral degree. 


\section{Assessment of reliability and validity}

We measured validity and reliability using Cronbach's alpha. In general, Cronbach's alpha, should be above 0.70 , though levels above 0.60 are acceptable in exploratory research, as Hair et al., (1998) point out. In our case, Cronbach's alpha is above 0.660 (see Table 1) for all factors. This indicates adequate reliability in relation to internal consistency, which is appropriate for the variables under study.

Table 1 Reliability assessment

\begin{tabular}{|c|c|c|c|c|}
\hline Factor & $\begin{array}{c}\text { Identification } \\
\text { of item }\end{array}$ & Item & Average & $\begin{array}{l}\text { Cronbach's } \\
\text { alpha }\end{array}$ \\
\hline \multirow{4}{*}{$\begin{array}{l}\text { Information } \\
\text { management (IM) }\end{array}$} & IM1 & The USB has a clearly defined policy on IM & 2.94 & \multirow{4}{*}{.919} \\
\hline & IM2 & The USB has a clearly defined strategy for IM & 2.84 & \\
\hline & IM3 & $\begin{array}{l}\text { The USB has efficient IMSs and uses them } \\
\text { actively and effectively }\end{array}$ & 2.83 & \\
\hline & IM4 & $\begin{array}{l}\text { The IMSs are readily adapted to user } \\
\text { requirements }\end{array}$ & 2.80 & \\
\hline \multirow{4}{*}{ KMS usage (SU) } & SU1 & I try to visit Pyxis frequently & 2.41 & \multirow{4}{*}{.663} \\
\hline & SU2 & Pyxis provides information that I need & 2.86 & \\
\hline & SU3 & Pyxis is used actively and efficiently & 2.54 & \\
\hline & SU4 & $\begin{array}{l}\text { Pyxis is closely integrated with the university's } \\
\text { processes }\end{array}$ & 2.98 & \\
\hline \multirow{4}{*}{ User satisfaction (US) } & US1 & Pyxis is useful & 3.23 & \multirow{4}{*}{.815} \\
\hline & US2 & $\begin{array}{l}\text { Pyxis improves the effectiveness of the } \\
\text { activities I perform }\end{array}$ & 2.89 & \\
\hline & US3 & My attitude toward Pyxis is favorable & 3.15 & \\
\hline & US4 & $\begin{array}{l}\text { Pyxis improves the quality and efficiency of } \\
\text { daily work }\end{array}$ & 3.35 & \\
\hline \multirow{3}{*}{ Perceived benefits (PB) } & PB1 & $\begin{array}{l}\text { The USB has KM processes that allow } \\
\text { knowledge to be used in daily functions }\end{array}$ & 2.72 & \multirow{3}{*}{.738} \\
\hline & PB2 & $\begin{array}{l}\text { The KMS is integrated with the institution's } \\
\text { daily functions and processes }\end{array}$ & 1.91 & \\
\hline & PB3 & $\begin{array}{l}\text { The information/knowledge provided by the } \\
\text { KMS is utilized in daily tasks }\end{array}$ & 1.81 & \\
\hline
\end{tabular}

To examine the uni-dimensionality/convergent validity of each predefined construct of multiple elements, we performed an explanatory factor analysis in the form of a principal component factor analysis with varimax rotation. The rotation matrix component is shown in Table 2. It is evident that there is no cross loading. The load factor for all variables is greater than 0.6, which is considered significant (Nunnally \& Bernstein, 1993), guaranteeing adequate convergent and discriminating validity. Table 3 presents the intermediation correlation analysis.

Table 2. Rotation matrix component

\begin{tabular}{lcccc}
\hline & \multicolumn{4}{c}{ COMPONENT } \\
\hline & $\begin{array}{c}\text { User satisfaction } \\
\text { (US) }\end{array}$ & $\begin{array}{c}\text { Information } \\
\text { management (IM) }\end{array}$ & KMS usage (SU) & $\begin{array}{c}\text { Perceived benefits } \\
\text { (PB) }\end{array}$ \\
\hline US1 & .872 & .067 & .179 & .083 \\
US2 & .829 & -.046 & .234 & .114 \\
US3 & .822 & .132 & .021 & .059 \\
SU2 & .777 & .232 & .058 & .104 \\
SU1 & .667 & .182 & .071 & .081 \\
\hline IM2 & .097 & .895 & .157 & .145 \\
IM3 & .148 & .881 & .112 & .073 \\
IM4 & .206 & .829 & .124 & .163 \\
IM1 & .100 & .824 & .309 & .110 \\
\hline
\end{tabular}


De Freitas, V. \& Yáber, G. (2018). Information management as a determinant of success in knowledge management systems. Journal of Business, Universidad del Pacífico (Lima, Peru) Vol.10 (2): 88-108

\begin{tabular}{lllll}
\hline SU3 & .079 & .244 & .814 & .124 \\
SU4 & .295 & .055 & .779 & .182 \\
SU4 & .090 & .307 & .730 & .164 \\
\hline PB3 & .061 & .243 & .127 & .820 \\
PB2 & .101 & .256 & .161 & .808 \\
PB1 & .153 &. .051 & .130 & .702 \\
\hline
\end{tabular}

Extraction method: Principal component analysis

Rotation method: Varimax with Kaiser normalization

a. Rotation converged in 7 iterations

Table 3. Intermediation correlation analysis

\begin{tabular}{lcccc}
\hline & US & IM & SU & BP \\
\hline PB & 1 & & & \\
IM & $.321^{* *}$ & 1 & & \\
SU & $.363^{* *}$ & $.465^{* *}$ & 1 & \\
PB & $.237^{*}$ & $.331^{* *}$ & $.357^{* *}$ & 1 \\
\hline${ }^{* *}$ The correlation is significant at the 0.01 level (bilateral) \\
${ }^{* *}$ The correlation is significant at the 0.05 level (bilateral)
\end{tabular}

\section{Regression analysis}

We used the regression analysis to test the five research hypotheses. We assessed the multicollinearity problem using the variance inflation factor (VIF). In theory, if the value of the VIF is lower than 10, it means that either there is a relationship between the variables or there is a problem in relation to the multiple relationships.

The results of the surveys are presented in tables $4,5,6,7$ and 8 .

Table 4. Information management has an impact on KMS usage

\begin{tabular}{cccccc}
\hline Variable & B & Beta & t & Sig. & VIF \\
\hline $\mathrm{IM}$ & .486 & .465 & 5.095 & $0.000 *$ & 1.000 \\
\hline$* \mathrm{P}<0.01 \mathrm{R}=.465^{\mathrm{a}}$ & $\mathrm{R}^{2}=.216 \mathrm{~F}=25.962$ & Sig. $=0.000^{*}$ \\
& & & \\
a. Predictive variable: (Constant), Information management & & &
\end{tabular}

Hypothesis 1: as can be observed in Table 4, IM has a positive Beta of .465 and a $p$ $<0.01$. That is, IM has a positive, statistically significant relationship with KMS usage and also has an influence on it. As such, Hypothesis 1 is accepted.

Table 5. KMS usage has an impact on user satisfaction

\begin{tabular}{cccccc}
\hline Variable & $\mathbf{b}$ & Beta & $\mathbf{t}$ & Sig. & VIF \\
\hline KMS usage & .335 & .363 & 3.771 & $0.000^{*}$ & 1.000 \\
\hline * $\mathrm{P}<0.01 \mathrm{R}=.363^{\mathrm{a}}$ & $\mathrm{R}^{2}=.131 \mathrm{~F}=14.223$ & Sig. & $=0.000^{*}$ \\
a. Predictive variables: (Constant), KMS usage
\end{tabular}

Hypothesis 2: Table 5 shows that KMS usage has a positive $\beta$ eta of .363 and a $p<$ $0.01^{*}$. It can therefore be discerned that KMS usage has a positive, statistically significant relationship with user satisfaction. This means that Hypothesis 2 is accepted.

Table 6. User satisfaction has an impact on KMS usage

\begin{tabular}{|c|c|c|c|c|c|}
\hline Variable & b & Beta & $t$ & Sig. & VIF \\
\hline $\begin{array}{c}\text { User } \\
\text { satisfaction }\end{array}$ & .393 & .363 & 3.771 & $0.000 *$ & 1.000 \\
\hline
\end{tabular}


De Freitas, V. \& Yáber, G. (2018). Information management as a determinant of success in knowledge management systems. Journal of Business, Universidad del Pacífico (Lima, Peru) Vol.10 (2): 88-108

a. Predictive variable: (Constant), User satisfaction

Hypothesis 3: Table 6 shows that user satisfaction has a positive $\beta$ eta of .363 and a $p$ $<0.01^{*}$. As such, user satisfaction has a statistically significant positive relationship with KMS usage. Thus, Hypothesis 3 is accepted.

Table 7. KMS usage has an impact on perceived benefits

\begin{tabular}{|c|c|c|c|c|c|}
\hline Variable & b & Beta & t & Sig. & VIF \\
\hline KMS usage & .501 & .357 & 3.708 & $0.000^{*}$ & 1.000 \\
\hline
\end{tabular}

Hypothesis 4: Table 7 shows that KMS usage has a positive ßeta of .357 and a $p<$ $0.01^{*}$. Thus, KMS usage does have a significant positive relationship with perceived benefits, so Hypothesis 4 is accepted.

Table 8. User satisfaction has an impact on perceived benefits

\begin{tabular}{|c|c|c|c|c|c|}
\hline Variable & b & ßeta & $\mathbf{t}$ & Sig. & VIF \\
\hline $\begin{array}{c}\text { User } \\
\text { satisfaction }\end{array}$ & .360 & .237 & 2.367 & $0.020^{*}$ & 1.000 \\
\hline
\end{tabular}

Hypothesis 5: Table 8 shows that user satisfaction has a positive ßeta of .257 and a $p$ $<0.01^{*}$. It is therefore concluded that user satisfaction does have a significant positive relationship with perceived benefits, so Hypothesis 5 is accepted.

The results are presented graphically in Figure 3.

Figure 3. Results of hypothesis tests

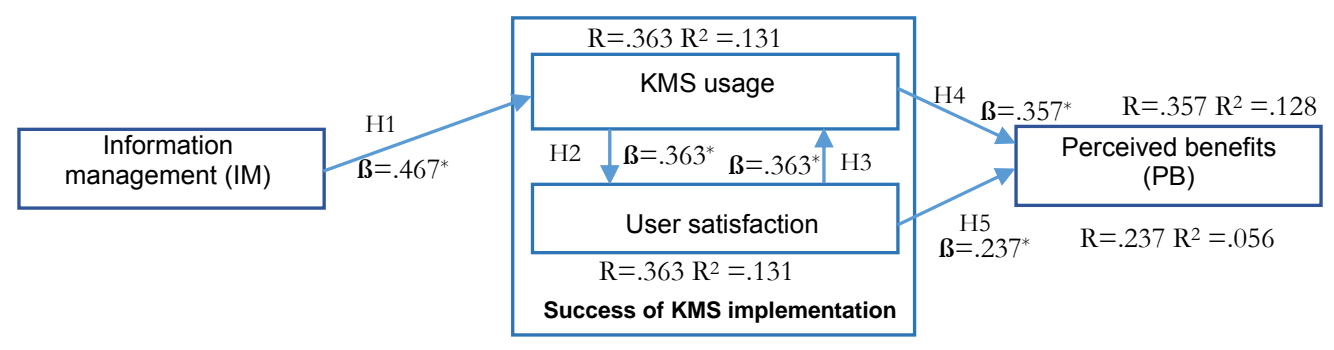

\section{Discussion of results}

The hypothesis tests show that information management has a positive effect on KMS usage, and that it is a success factor in the implementation of these systems. Moreover, we find that KMS usage and user satisfaction have a positive, statistically significant relationship with perceived benefits. We also find that the KMS has greater impact on perceived benefits than it does on user satisfaction. In addition, our results show that user satisfaction has a positive relationship with KMS usage; that is, if employees are satisfied with the system's efficiency and effectiveness, they will be willing to use it. Even if its effect is less influential on perceived benefits, user satisfaction is an important 
measurement of success in KMS implementation. This being the case, those in charge of KM processes should bear in mind that KMSs need to cater for users' needs, and to be better adapted to this end.

\section{Conclusions}

In this study we illustrated the importance of information management as a success factor in the implementation of knowledge management in an academic context. We did so by applying a questionnaire, using a qualitative method, to 96 informants who work at the Universidad Simón Bolívar, which has implemented a knowledge management system known as Pyxis. We based our model on the proposals of De Freitas and Yáber (2014); Stankosky (1999); Bustelo and Amarilla (2001); DeLone and McLean (2003); Halawi et al., (2008); Suárez (2009); Nattapol el al., (2010); Cáceres (2011); Jennex and Olfman (2011); and Astuti and Suryadi (2015), who point to IM as an important element in the KM process. All of the proposed hypotheses (5) were accepted. We propose that those responsible for KM should consider IM as a success factor in KMS implementation.

Our results attest to the importance of IM, since it plays an important part in knowledge - namely, in explicit knowledge, understood as information. IM should also be supported by human resource management and its culture through mechanisms that enable exchange between workers, aided (though not exclusively) in turn by technology, with a view to sharing experiences and knowledge. The findings coincide with UNESCO's (2005) assertion that information societies provide tools for the accumulation of information, while knowledge societies use these tools in reasoning processes. It is evident that for HEls to develop in demanding and competitive environments created in the knowledge economy or in knowledge societies, they must manage their human capabilities and take advantage of the resources provided by IM and KM. In so doing, they can obtain sustainable competitive advantages that are reflected in better performance and quality levels in teaching, research, extension, and management.

\section{Bibliography}

Al-Hayaly, M.A.M. y Alnajjar, F.J.S. (2016). Knowledge Management Processes and Their Impact on Organizational Performance, the Adoption Balanced Scorecard: The Moderating Role of Quality Assurance Standards-An Applied Study on Private Jordanian Universities. International Journal of Business and Management, 11(6), 70.

Almuiñas, J.L., Passailaigue, R. \& Galarza, J. (2015). La Gestión de la Información y el Conocimiento: Una Oportunidad para las Instituciones de Educación Superior. Revista Universidad y Sociedad, 7(3), 16-22.

Astuti, A.Y. \& Suryadi, K. (2015). Assessing Knowledge Management Systems' Success Based on Technical and Social Factors. Proceeding 8th International Seminar on Industrial Engineering and Management (8th ISIEM), 8.

Aubert, B.; Bernard, J. G. \& Caro-Gonzalez, C. (2011). Defining Knowledge Management System Risk. PACIS, 21. 
De Freitas, V. \& Yáber, G. (2018). Information management as a determinant of success in knowledge management systems. Journal of Business, Universidad del Pacífico (Lima, Peru) Vol.10 (2): 88-108

Barney, J. (1991). Firm Resources and Sustained Competitive Advantage. Journal of Management, 17(1), 99-120.

Barney, J.; Wright, M. \& Ketchen, D. (2001). The Resource-based View of the Firm: Ten years after 1991. Journal of Management, 27(6), 625-641.

Blanchard, K.O.C. (2000). Dirección por Valores. Barcelona: Gestión.

Bradley, K. (1997). Intellectual Capital and the New Wealth of Nations. Business Strategy Review, 8(1), 53-62.

Bustelo, C. \& Amarilla, R. (2001). Gestión del Conocimiento y Gestión de la Información. Inforarea S.L. Boletín del Instituto Andaluz de Patrimonio Histórico, VIII(34), 226-230.

Cáceres, M.A. (2011). Modelo de Gestión del Conocimiento Estratégico para la Facultad de Ingeniería y Arquitectura de la Universidad de San Martín De Porres. Cultura, 25, 305-322.

Carneiro, A. (2000). How does Knowledge Management Influence Innovation and competitiveness? Journal of Knowledge Management, 4(2), 87-98.

Centro Interuniversitario de Desarrollo (1997). Cooperación en Políticas y Mecanismos sobre Docencia Universitaria. Centro Interuniversitario de Desarrollo.

Cruz, R. (2012). La Gestión del Conocimiento y la Innovación en Servicios de Telecomunicaciones en las Empresas de México. Innovaciones de Negocios, 9(18), 367-384.

De Freitas, V. \& Yáber, G. (2014). Modelo Holístico de Sistema de Gestión del Conocimiento para las Instituciones de Educación Superior. Enl@ce: Revista Venezolana de Información, Tecnología y Conocimiento, 11(3), 123-154.

DeLone, W.H. \& McLean, E.R. (2003). The DeLone and McLean Model of information Systems Success: A Ten-Year Update. Journal of Management Information Systems, 19(4), 9-30.

Escobar, A.; Velandia, G. \& Navarro, E. (2018). Gestión del Conocimiento y Competitividad en las Cooperativas con Sección de Ahorro y Crédito. REVESCO: Revista de Estudios Cooperativos, 127, 90-115.

Flores, M. \& Ramírez, R. (2011). Intermediación de Conocimiento: Proceso de la Gestión del Conocimiento en Cooperativas Agropecuarias Venezolanas. Revista Venezolana de Gerencia, 55(16), 458-473.

Fotache, G. (2013). Comparative Study Regarding Information Management and Knowledge Management. Economy Transdisciplinarity Cognition, 16(2), 63-70.

Garita, W.A. (2015). Reflexiones e Insumos sobre los Sistemas de Información Gerencial en la Gestión de las Instituciones de Educación Superior: Ventajas y Desventajas. Gestión de la educación, 5(2), 23-37.

Gates, B (1999). Business @ the Speed of Thought, Viking Ringwood, Victoria: Viking (Penguin Books).

Gómez-Vargas, M. \& García, M. (2015). Factores Influyentes de la Gestión del Conocimiento en el Contexto de la Investigación Universitaria. Información, Cultura y Sociedad, (33), 29-46. 
De Freitas, V. \& Yáber, G. (2018). Information management as a determinant of success in knowledge management systems. Journal of Business, Universidad del Pacífico (Lima, Peru) Vol.10 (2): 88-108

Grant, R.M. (1991). The Resource Based Theory of Competitive Advantage: Implications for Strategy Formulation. California Management Review, 33(3), 114-135.

Guzmán, C.; Santos, F. \& Barroso, M.O. (2015). Cooperativismo, Factor Empresarial y Desarrollo Económico: Propuesta de un Modelo Teórico de Enlace. REVESCO: Revista de Estudios Cooperativos, 122, 110-134.

Hair, J.F.; Anderson, R.E.; Tatham, R.L. \& Black, W.C. (1998). Multivariate Data Analysis. Upper Saddle River, New Jersey: Prentice Hall.

Halawi, A.L.; McCarthy, R.V. \& Aronson, J.E. (2008). An Empirical Investigation of Knowledge Management Systems Success. The Journal of Computer Information Systems, 48(2), 121-135.

Hall, R. (1992). The Strategic Analysis of Intangible Resources. Strategic Management Journal, 13(2), 135-144.

Hall, R. (2006). A Framework Linking Intangible Resources and Capabilities to Sustainable Competitive Advantage. Strategic Management Journal, 14(8), 607-618.

luga, V. \& Kifor, C.V. (2014). Information and Knowledge Management and their Interrelationship within lean Organizations. Buletin Stiintific, 1(37), 31-38.

Jennex, M.E. (2017). Re-Examining the Jennex Olfman Knowledge Management Success Model. In Proceedings of the 50th Hawaii International Conference on System Sciences.

Jennex, M.E. \& Olfman, L. (2011). A Model of Knowledge Management Success. In Jennex, M.E. \& Smolnik, S. (ed). Strategies for Knowledge Management Success: Exploring Organizational Efficacy. Hersey, New York: Information Science Reference. Pp. 14-31.

Kane, A.A. (2010). Unlocking Knowledge Transfer Potential: Knowledge Demonstrability and Superordinate Social Identity. Organization Science, 21(3), 643-660.

Kazemi, M. \& Allahyari, M.Z. (2010). Defining a Knowledge Management Conceptual Model by Using MADM. Journal of Knowledge Management, 14(6), 872-890.

Kotecki, P. (2011). Building Organizational Capability: A Study of Knowledge Management Practices Reasons, and Results. PhD. Dissertation, Capella University.

Kutner, M.H.; Nachtsheim, C.J.; Neter, J. \& Li, W. (2005). Applied Linear Statistical Models. Boston: McGraw-Hill.

Llorente, I. (2013). Análisis de Competitividad de las Empresas de Acuicultura. Aplicaciones Empíricas al Cultivo de la Dorada (Sparus Auratha) y la Lubina (Dicentrarchus labrax) (Doctoral thesis). Universidad de Cantabria, Santander, Spain.

López, P. (2011). Aprendizaje Colaborativo para la Gestión de Conocimiento en Redes Educativas en la Web 2.0. (Doctoral tesis). Universidad Nacional de Educación a Distancia, Spain.

Luengo, M.J. \& Obeso, M. (2013). Efeito da hélice Tríplice em Desempenho de Inovação. RAE-Revista de Administração de Empresas, 53(4), 388-399. 
De Freitas, V. \& Yáber, G. (2018). Information management as a determinant of success in knowledge management systems. Journal of Business, Universidad del Pacífico (Lima, Peru) Vol.10 (2): 88-108

Maier, R. (2007). Knowledge Management Systems. Information and Communication Technologies for Knowledge Management. New York: Springer.

Makori, E.O. (2009). Contemporary issues in Information Management: A Fresh Look for Information Professionals. International Journal of Library and Information Science, 1(6), 082-091.

Milam, J. (2005). Organizational Learning Through Knowledge Workers and Infomediaries. New Directions for Higher Education, 2005(131), 61-73.

Morales, V.; Medina, E. \& Álvarez, N. (2003). La Educación Superior en Venezuela. Informe 2002 a IESALC. Caracas, Venezuela: UNESCO. 90 pp.

Naranjo, C.G. (2011). El Liderazgo en la Gestión del Conocimiento. Perspectivas en Psicología, 10, 1-20.

Naranjo, S.; González, D.L. \& Rodríguez, J. (2016). El Reto de la Gestión del Conocimiento en las Instituciones de Educación Superior Colombianas. Folios, (44), 151-164.

Nattapol, N.; Peter, R. \& Laddawan, K. (2010). An Investigation of the Determinants of Knowledge Management Systems Success in Banking Industry. World Academy of Science, Engineering and Technology, 71(1), 588-595.

Nonaka, I. \& Takeuchi, H. (1995). The Knowledge Creating Company. Oxford University Press.

Noordin, M.F.; Othman, R. \& Zakaria, N.A. (2013). Investigating Key Success Factors in Adopting Knowledge Management System. World Applied Sciences Journal, 21(2), 221229.

Nunnally, J.C. \& Bernstein, I.H. (1993). Psychometric Theory. New York: McGraw-Hill.

Núñez, Y. \& Rodríguez, C. (2014). Árboles de Clasificación para Jerarquizar los Recursos Intangibles Asociados a la Innovación en las Instituciones de Educación Superior Latinoamericanas. Interciencia: Revista de Ciencia y Tecnología de América, 710(31), pp. 703-710.

Ooi, K. (2009). TQM and Knowledge Management: Literature Review and Proposed Framework. African Journal of Business Management, 3(11), 633-643.

Orozco, E. (2004). Propuesta de Estrategia para la Introducción de la Gestión de la Información y la Gestión del Conocimiento en las Organizaciones Cubanas. En Memorias del Congreso Internacional de Información, INFO' 2004, April 12-16, [CD ROM].

Otálora, J. \& Vásquez, L. (2016). Metodología ABC para el Fortalecimiento de la Gestión de Costos en las Cooperativas de Ahorro y Crédito de Barranquilla (research financed by COLCIENCIAS convocatoria 702, 2015 and Universidad de la Costa Convocatoria 11, 2015). Universidad de la Costa, Barranquilla, Colombia.

Penrose, E. (1959). The Theory of the Growth of the Firm Basic. London, United Kingdom: Basic Blackwell. 249 p. 
Peraza, E.; Gómez, J. \& Aleixandre, G. (2016). Los Factores Determinantes del Comportamiento Innovador de las Cooperativas: Un Análisis para el Caso de Castilla y León. REVESCO: Revista de Estudios Cooperativos, 122(3), 252-284.

Pircher, R. \& Pausits, A. (2011). Information and Knowledge Management at Higher Education Institutions. Management Information Systems, 6(2), 8-16.

Polanyi, M. (1998). The tacit dimension. Reprinted in Knowledge in Organization (Prusak, L. ed.). Boston: Butterworth-Heinemann, 135-146.

Ponjuán, G. (1998). Gestión de la Información en las Organizaciones: Principios, Conceptos y Aplicaciones. CECAPI. Chile.

Ponjuán, G. (2005). Gestión Documental, Gestión de Información y Gestión del Conocimiento: Evolución y Sinergias. Comunicación Preliminar. Ciencias de la Información, 36(3), 67-71.

Porter, M. (1991). La Ventaja Competitiva de las Naciones. Buenos Aires, Argentina: Vergara Editor S.A. 1020 p.

Pubillones, H. (2004). Mapas de Conocimientos en una Vicepresidencia de Prensa Latina, Agencia Informativa Latinoamericana, S.A. (Undergraduate thesis), Universidad de La Habana. Cuba.

Rodríguez, M.T. \& González, J.J. (2013). Gestión del Conocimiento y Capital Intelectual, a través de Modelos Universitarios. Revista Económicas CUC, 34(1), 85-116.

Rodríguez-Ponce, E.; Pedraja-Rejas, L.; Araneda-Guirriman, C. \& Rodríguez-Ponce, J. (2013). La Relación entre la Gestión del conocimiento y la Gestión Académica: Un Estudio Exploratorio en Universidades Chilenas. Interciencia, 38 (2), 88-94.

Rueda, M.I. (2014). La Gestión del Conocimiento y la Ciencia de la Información: Relaciones Disciplinaria y Profesionales. (Doctoral thesis), Universidad Carlos III de Madrid.

Ruzic-Dimitrijevic, L. (2014). Risk Assessment of Knowledge Management System. Online Journal of Applied Knowledge Management, 3(2), 114-126.

Sáiz, L.; Díez, J.I.; Manzanedo, M.A. \& Rodríguez, C. (2013). Intercambio del Conocimiento en la Empresa. Aprendiendo de la experiencia. Interciencia: Revista de Ciencia y Tecnología de América, 38(8), 570-576.

Sánchez, M. \& Vega, J.C. (2006). La Gestión del Conocimiento y su Relación con otras Gestiones. Ciencias de la Información, 37(2-3), 35-52.

Shaikh, J. (2004). Measuring and Reporting of Intellectual. Capital Performance Analysis. The Journal of American Academy of Business, 4(1-2), 439-448.

St Clair, G. (2001). Knowledge Services: Your Company's Key to Performance Excellence. Information Outlook, 5(6), 6-8.

Stankosky, M. (1999). A Theoretical Framework. KM World, 8(3).

Suárez, N. (2009). Modelo de Gestión de Conocimiento para la USC. Revista Ingenlum, Ciencia y Tecnología, 4(8), 226-248. 
Teece, D.J. (2005). Technology and Technology Transfer: Mansfieldian Inspirations and Subsequent Developments. Journal of Technology Transfer, 30(1-2), 17-33.

UNESCO (2005). Hacia las sociedades del conocimiento. Paris: Unesco Publications. Universidad Central de Venezuela (2013). Retrieved from: www.ucv.ve/navegacionhorizontal/areas/areas-generales/de-interes/universidades-publicas-nacionales.html.

Varela-Candamio, L. \& García-Álvarez, M. (2012). Analysis of Information and Communication Technologies in Higher Education: A Case Study of Business Degree. The International Journal of Engineering Education, 28(6), 1301-1308.

Woodman, L. (1985). Information Management in Large Organizations. In: Cronin, Blaise (ed.). Information Management from Strategies to Action. London: ASLIB, pp. 95-114. 